\title{
Delaying Harvest Improves Bell Pepper Yield
}

\section{V.M. Russo \\ U.S. Department of Agriculture, Agricultural Research Service, South Central Agricultural Research Laboratory, P.O. Box 159, Lane, OK 74555}

Additional index words. culture, harvest scheduling, plant development

\begin{abstract}
Delaying or limiting the number of harvests could improve yield and reduce inputs in bell pepper (Capsicum annuum var. annuum $\mathbf{L}$.) production. Fruit were harvested in a variety of timing methods, which include three times over 14 days with the second and third harvests occurring 7 and 14 days after the first. Fruit from other plants were harvested once at either 7 or 14 days after the first harvest from plants that had several harvests. Fruit length was not affected by time of harvest. Number of marketable fruit, fruit width at the shoulder, endocarp thickness, and fruit volume were increased in fruit from plants harvested once. Marketable yields from plants with a single harvest were, on average, 1.5-fold higher than those from plants with several harvests. Delaying harvests improved fruit quality and quantity. Limiting number of harvests would reduce passes through the field and the associated costs, possibly improving net income.
\end{abstract}

Pepper fruit formed on the first three nodes are closer to the nutrient source (Ali and Kelly, 1992). These fruit are larger than branch fruit (Gaye et al., 1992). It is the fruit formed on the first three nodes that are preferred because of their size; also, these fruit may be efficiently harvested with a single pass. If the harvest is delayed, the fruit from the first three nodes could increase in grade, and subsequently formed branch fruit also might increase in size or grade. This study was conducted to determine if delaying harvests increased marketable bell pepper fruit quality and quantity.

\section{Materials and Methods}

Peppers ('Pip') were grown on raised beds $(20 \mathrm{~cm}$ high $\times 3.7 \mathrm{~m}$ long $\times 76 \mathrm{~cm}$ wide, on 1.8 $\mathrm{m}$ centers) oriented east-west on a Bernow fine-loamy, siliceous, thermic Glossic Paleudalf soil at Lane, Okla. $a, a, a$-trifluoro2,6-dinitro- $N, N$-dipropyl-p-toluidine (trifluralin) herbicide was applied, with water adjusted to $\mathrm{pH} 6.5$, at bed formation. Fertilizer was applied in bed centers at $65 \mathrm{~N}-85 \mathrm{P}-170 \mathrm{~K}$ $\mathrm{kg} \cdot \mathrm{ha}^{-1}$ in response to soil tests. Supplemental water was applied by drip irrigation (T-tape, emitters on 23-cm centers; Zimmerman Irrigation, Mifflinburg, $\mathrm{Pa}$.) so that on average 25 $\mathrm{mm} \cdot \mathrm{h}^{-1}$ was delivered to each plant. Greenhouse-grown, 6-week-old pepper seedlings were transplanted at an in-row spacing of 46 cm on 16 Apr. 1992 and 30 Apr. 1993.

Fruit were harvested using four timings: 1) twice, with the first harvest when fruit in the first axil had reached marketable size [at least US \#1 grade minimum $6.4 \times 6.4-\mathrm{cm}$ length and width; U.S. Dept. of Agriculture (USDA), 1989], and again 7 days later for any remaining marketable fruit; 2) once, 7 days after the first harvest in treatment $1 ; 3$ ) three times, with the first harvest at the same time as in treatment 1 , and again 7 and 14 days later for any remaining marketable fruit; and 4) once, 14 days after the first harvest in treatment 1 . Intervals between transplanting and harvest were 1) 78 and 85 days in 1992 and 53 and 60 days in 1993;2) 85 days in 1992 and 60 days in 1993; 3) 78, 85, and 92 days in 1992 and 53, 60, and 67 days in 1993; and 4) 92 days in 1992 and 67 days in 1993.

Seven marketable fruit from each harvest time were chosen at random. Fruit length from blossom end to the top of the shoulder and width at the fruit shoulder and flower end were measured. Then disks (21 $\mathrm{mm}$ in diameter) were cut from fruit in flat areas and the thickness from the exocarp to the endocarp determined. Fruit volume was mathematically derived using the formula for a cone. For each harvest method, marketable fruit were counted, segregated by grade, and weighed.
Harvest timings were arranged in a randomized complete-block design and replicated four times. Data were analyzed with the General Linear Models procedures in SAS (SAS Inst., 1988).

\section{Results and Discussion}

Marketable fruit counts and yield were affected by harvest method (Table 1). When harvest was delayed (timing 2 and 4), significantly more marketable fruit were produced. In 1992, the ratio of fancy : US \#1 fruit was significantly higher for plants that had a single delayed harvest than for plants that had several harvests. This ratio was not affected by harvest method in 1993, and the 1993 ratios of fancy : US \#1 fruit for each treatment was higher than in 1992. Plants with a single harvest delayed 14 days in both years produced higher marketable yields than plants with three harvests and no delays. In 1993, marketable yield from plants with a single harvest delayed 7 days was significantly higher than for plants with two harvests. Fruit at all harvests exceeded length and width at the shoulder requirements for US \#1 grade (average $8.1 \times 7.7$ $\mathrm{cm}$; USDA, 1989), and were within the size criteria of what is expected for this cultivar. Fruit length and width, endocarp thickness, and fruit weight and volume were affected by harvest timing (Table 2). Length of fruit from plants harvested once was equal to, or greater than, that from plants with several harvests. Fruit from plants with a single delayed harvest were wider, had thicker fruit endocarp, were heavier, and had a larger fruit volume than those from plants with several harvests.

Marketable size can be achieved even if fruit weight appears to be light. This relationship was particularly true in 1992 where the fruit from plants that had several harvests were of marketable size at harvest even though they weighed only $\approx 100 \mathrm{~g}$, which suggests that fruit endocarp development was not completed even though fruit were of marketable size. Delaying harvest increased not only fruit size, but also the thickness of the endocarp.

Asgrow Seed (Kalamazoo, Mich.) suggests that 'Pip' pepper matures at 75 days after transplanting (unpublished). However, environmental conditions can affect time to maturity (Stofella et al., 1995). The shorter time to harvest in 1993 was likely due to a combination of delayed planting due to wet soils and cool, wet weather for 2 weeks after transplant-

Received for publication 11 Oct. 1995. Accepted for publication 13 Jan. 1996. Mention of a trademark, vendor, or proprietary product does not constitute a guarantee or warranty of the product by the U.S Dept. of Agriculture and does not imply its approval to the exclusion of other products that may also be suitable. The cost of publishing this paper was defrayed in part by the payment of page charges. Under postal regulations, this paper therefore must be hereby marked advertisement solely to indicate this fact.

Table 1. Effect of harvest timing on marketable fruit count, ratio of fancy : marketable fruit, and marketable yield of bell pepper.

\begin{tabular}{|c|c|c|c|c|c|c|}
\hline \multirow[b]{2}{*}{ Harvest timing } & \multicolumn{2}{|c|}{$\begin{array}{l}\text { Marketable fruit } \\
\text { (No./ha, 1000s) }\end{array}$} & \multicolumn{2}{|c|}{$\begin{array}{c}\text { Ratio fancy : } \\
\text { US \#1 fruit }\end{array}$} & \multicolumn{2}{|c|}{$\begin{array}{c}\text { Marketable } \\
\text { fruit yield } \\
\left({\left.\mathrm{Mg} \cdot h a^{-1}\right)}\right.\end{array}$} \\
\hline & 1992 & 1993 & 1992 & 1993 & 1992 & 1993 \\
\hline Twice & $8 b^{2}$ & $6 \mathrm{~b}$ & $0.00 \mathrm{~b}$ & $0.53 \mathrm{a}$ & $1.8 \mathrm{~b}$ & $2.0 \mathrm{c}$ \\
\hline Once, delayed 7 days $^{y}$ & $20 \mathrm{a}$ & $17 \mathrm{a}$ & $0.23 \mathrm{a}$ & $0.61 \mathrm{a}$ & $2.3 \mathrm{ab}$ & $2.4 \mathrm{~b}$ \\
\hline Three times & $10 \mathrm{~b}$ & $8 \mathrm{~b}$ & $0.00 \mathrm{~b}$ & $0.43 \mathrm{a}$ & $2.0 \mathrm{~b}$ & $2.5 \mathrm{~b}$ \\
\hline Once, delayed 14 days $^{\mathrm{y}}$ & $38 \mathrm{a}$ & $23 \mathrm{a}$ & $0.15 \mathrm{a}$ & $0.88 \mathrm{a}$ & $3.6 \mathrm{a}$ & $3.9 \mathrm{a}$ \\
\hline
\end{tabular}

${ }^{2}$ Mean separation within columns by Duncan's multiple range test $(P \leq 0.05)$.

${ }^{y}$ Based on days following first harvest of plants that had two or three harvests. 


\section{Crop Production}

Table 2. Effect of harvest timing on marketable fruit characteristics.

\begin{tabular}{lccccc}
\hline \hline & \multicolumn{5}{c}{ Mean marketable fruit } \\
\cline { 2 - 6 } & $\begin{array}{c}\text { Length } \\
(\mathrm{cm})\end{array}$ & $\begin{array}{c}\text { Width } \\
(\mathrm{cm})\end{array}$ & $\begin{array}{c}\text { Endocarp } \\
\text { thickness } \\
(\mathrm{mm})\end{array}$ & $\begin{array}{c}\text { Wt } \\
(\mathrm{g})\end{array}$ & $\begin{array}{r}\text { Vol } \\
\text { Harvest timing }\end{array}$ \\
\hline & $7.7 \mathrm{ab}^{\mathrm{z}}$ & 1992 & & \\
Twice & $8.1 \mathrm{a}$ & $9.1 \mathrm{c}$ & $5.2 \mathrm{~b}$ & $101 \mathrm{c}$ & $322 \mathrm{~b}$ \\
Once, delayed 7 days & $7.6 \mathrm{ab}$ & $7.0 \mathrm{c}$ & $5.0 \mathrm{a}$ & $182 \mathrm{a}$ & $527 \mathrm{a}$ \\
Three times & $7.2 \mathrm{~b}$ & $8.2 \mathrm{~b}$ & $6.1 \mathrm{a}$ & $97 \mathrm{c}$ & $299 \mathrm{c}$ \\
Once, delayed 14 days & & 1993 & & & $383 \mathrm{~b}$ \\
& $8.0 \mathrm{~b}^{\mathrm{y}}$ & $7.0 \mathrm{~b}$ & $5.4 \mathrm{~b}$ & $130 \mathrm{~b}$ & $310 \mathrm{~b}$ \\
Twice & $9.0 \mathrm{a}$ & $7.8 \mathrm{a}$ & $6.6 \mathrm{a}$ & $163 \mathrm{a}$ & $439 \mathrm{a}$ \\
Once, delayed 7 days & $8.0 \mathrm{~b}$ & $7.1 \mathrm{~b}$ & $6.1 \mathrm{~b}$ & $131 \mathrm{~b}$ & $317 \mathrm{~b}$ \\
Three times & $8.7 \mathrm{ab}$ & $8.0 \mathrm{a}$ & $7.3 \mathrm{a}$ & $181 \mathrm{a}$ & $442 \mathrm{a}$ \\
Once, delayed 14 days & $\mathrm{y}$ & &
\end{tabular}

${ }^{2}$ Mean separation within columns and years by Duncan's multiple range test $(P \leq 0.05)$.

${ }^{\mathrm{y}}$ Based on days following first harvest of plants that had two or three harvests.

ing, which was followed by hot, dry conditions through harvest. The combination of weather factors may have contributed to the divergent trends in the ratio of fancy : US \#1 grade fruit in the two years. This supposition is supported by other research that found that cool soil temperatures slowed plant development (Rylski, 1972), and nights between 18 and $20 \mathrm{C}$ are suitable for pepper flowering and fruit development (Deli and Tiessen, 1969; Rylski, 1973; Tiessen, 1962).

In many commercial bell pepper production areas, one to four harvests are expected. In this study, a single delayed harvest improved yield over those of plants harvested two or three times. Based on fruit size, the earliest harvest was not premature. For 'Pip' at our location, a single delayed harvest improved marketable yield on average 1.5 -fold over that of plants with several harvests. The reason for improved yield from plants harvested only once deserves further research. Reducing the number of harvests while maintaining fruit yields likely reduces production costs and improves harvesting efficiency, which may result in improved net profits to the grower.

\section{Literature Cited}

Ali, A.M. and W.C. Kelly. 1992. The effects of interfruit competition on the size of sweet pepper (Capsicum апnиит L.) fruits. Sci. Hort. 52:69-76.

Deli, J. and H. Tiessen. 1969. Interaction of temperature and light intensity on flowering of Capsicumfrutescens var grossum cv. California Wonder. J. Amer. Soc. Hort. Sci. 94:349-351.

Gaye, M.M., G.W. Eaton, and P.A. Joliffe. 1992. Rowcovers and plant architecture influence development and spatial distribution of bell pepper fruit. HortScience 27:397-399.

Rylski, I. 1972. Effect of the early environment on flowering in pepper (Capsicum аппиит L.). J. Amer. Soc. Hort. Sci. 97:648-651.

Rylski, I. 1973. Effect of night temperature on shape and size of sweet pepper (Capsicum aпnиит L.). J. Amer. Soc. Hort. Sci. 98:149-152.

SAS Institute. 1988. SAS/STAT user's guide. Release 6.03. SAS Inst., Cary, N.C.

Stofella, P.J., S.J.Locascio, T.K. Howe, S.M. Olson, K.D. Shuler, and C.S. Vavrina. 1995. Yield and fruit size stability differs among bell pepper cultivars. J. Amer. Soc. Hort. Sci. 120:325-328.

Tiessen, H. 1962. The influence of various temperatures and (2-chloroethyl) trimethylammonium chloride and (allyl), trimethylammonium bromide on peppers and tomatoes. Can. J. Plant Sci. 42:142-149.

U.S. Department of Agriculture. 1989. United States standards for grades of sweet peppers (as amended 3 Jan. 1989). Agr. Mktg. Serv., Washington, D.C. 